\title{
A STUDY OF THE DIURETIC ACTION OF ACID PRODUCING SALTS
}

\author{
By JAMES L. GAMBLE, KENNETH D. BLACKFAN, AND BENGT HAMILTON* \\ (From the Medical Clinic of the Children's Hospital and the Department of Pediatrics, The \\ Harvard Medical School, Boston)
}

(Received for publication, November 28, 1924)

CONTENTS

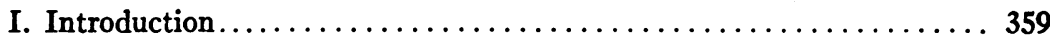

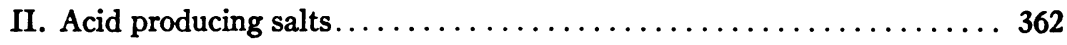

III. Increase in plasma acidity accompanying diuretic action of acid producing salts................................. 364

IV. Factors in causation of increased plasma acidity by acid producing salts. 367

V. Increase in fixed base excretion in urine following ingestion of acid producing salts and behavior of factors of acid excretion......... 372

VI. Composition of fixed base excretion following ingestion of calcium chloride................................. 382

VII. Discussion .................................... 385

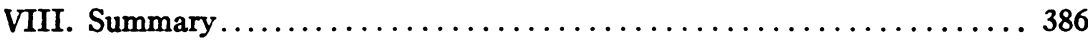

\section{INTRODUCTION}

Since the work of Blum (1) several years ago, a number of observers $(2,3,4)$ have accredited calcium chloride as an effective agent for the removal of edema fluid. In explanation of the diuretic action of this salt Blum suggested an antagonism in the body fluids between sodium and calcium with the consequence that when calcium intake is greatly raised by ingestion of a calcium containing salt, an increased excretion of sodium is produced. In support of this hypothesis, he has demonstrated an increased excretion of sodium in the urine and occassionally a measurable lowering of this base in blood plasma when $\mathrm{CaCl}_{2}$ is given in the presence of edema. Sodium retention being regarded as responsible for edema, its increased removal is supposed to permit secretion by the kidney of the super-

* The measurements presented in this paper were to a considerable extent obtained with the assistance of Anne C. Messer and Pauline Marsh.

The authors are also indebted to Dr. Gerald Hoeffel for the determinations of plasma $\mathrm{pH}$ given in table 1 . 
fluous body water. According to the conceptions of Fischer (5), a diuresis from $\mathrm{CaCl}_{2}$ would be referred to $\mathrm{Ca}{ }^{*}$ which, having in some way escaped the opposing effect of the $\mathrm{Cl}^{\prime}$ ion, operates as base against an increased acidity of the body fluids regarded as responsible for the pathological retention of water. That actually quite the inverse of such an effect follows ingestion of $\mathrm{CaCl}_{2}$ has been demonstrated by Gamble, Ross and Tisdall (6) and by Gamble and Ross (7) in their studies of the therapeutic action of several of the agents used in the treatment of infantile tetany. They found $\mathrm{CaCl}_{2}$ to be in large part, from the point of view of acid-base metabolism an acid substance. Following its ingestion there occurs an increase in the titratable acidity of the urine and a rise in urnary ammonia. The extension of these two factors together amounts usually to about one-half the equivalence of the $\mathrm{Cl}^{\prime}$ content of the ingested salt, so that to this extent, as regards adjustments necessary in the body fluids and in the process of acid excretion, $\mathrm{CaCl}_{2}$ taken orally is in effect $\mathrm{HCl}$. Measurements of $\mathrm{Ca}^{*}$ and $\mathrm{Cl}^{\prime}$ in stools and urine indicate that this acid effect of ingested $\mathrm{CaCl}_{2}$ is due to a much greater absorption of $\mathrm{Cl}^{\prime}$ than of $\mathrm{Ca}{ }^{*}$. In these studies ingestion of $\mathrm{CaCl}_{2}$ was observed to produce large alterations of acid-base factors in the blood plasma and in the urine. There occurred a marked reduction of plasma bicarbonate corresponding closely to an extension of chloride and accompanied by a considerable increase in plasma acidity. The urine was found to contain a much increased amount of fixed base. Although these infants were not edematous, these changes in the plasma and urine were found to be accompanied by a large increase in the volume of urine. These findings obviously suggest the possibility of a relationship between the acid effect produced by $\mathrm{CaCl}_{2}$ and its diuretic action. That this relationship exists and that the loss of body water which this salt causes is not due to some specific action by calcium was clearly indicated by the finding of Gamble and Ross (7) that $\mathrm{NH}_{4} \mathrm{Cl}$ given to an infant with tetany caused exactly the same alterations in the blood plasma and the same increase of fixed base excretion in the urine as does $\mathrm{CaCl}_{2}$ and also produced a definite diuresis. That $\mathrm{NH}_{4} \mathrm{Cl}$ taken orally produces an acidosis had been shown by J. B. S. Haldane (8). The acid effect of this salt is apparently due to transport of the ingested $\mathrm{NH}_{4}^{\circ}$ as urea, thus uncovering $\mathrm{Cl}^{\prime}$ which claims base in the body fluids at the expense of $\mathrm{BHCO}_{3}$. In a paper published at the same time as those just cited $(6,7)$, Haldane, Hill and Luck (9) reported the production of marked acidosis in normal subjects by ingestion of $\mathrm{CaCl}_{2}$. They suggested that the diuretic action of this salt is probably due to its acid effect rather than to an antagonism between $\mathrm{Ca}^{*}$ and $\mathrm{Na}{ }^{\circ}$ as maintained by Blum and made the surmise that $\mathrm{NH}_{4} \mathrm{Cl}$ would be found as effective an agent for removal of edema fluid as $\mathrm{CaCl}_{2}$. In a paper recently published, Keith, Barrier and Whelan (10) report an excellent diuresis in the presence of edema in nephritis produced by giving ammonium chloride.

In this paper it is desired to present data which further demonstrate that a loss of body water is in some way a consequence of ingestion of a 
salt from which inorganic acid radicals enter the body fluids accompanied to a relatively slight extent by fixed base. In addition to $\mathrm{CaCl}_{2}$ and $\mathrm{NH}_{4} \mathrm{Cl}, \mathrm{MgSO}_{4}$ and $\left(\mathrm{NH}_{4}\right)_{2} \mathrm{SO}_{4}$ are salts which may be expected to behave in this manner and may in this sense be described as "acid producing." We have undertaken to observe and compare effects produced by ingestion of these four salts. The chief purpose of this study was to note in detail and explain if possible, alterations of acid-base values in blood plasma and in urine accompanying diuresis produced by these agents. The plan of study consisted in obtaining the desired measurements before, and again during, and following a period of salt administration; the subject receiving throughout the observation period a diet ${ }^{1}$ accurately constant as regards its acid-base composition. It was further undertaken to compare findings obtained in the presence and in the absence of edema. The data to be presented are from but three children. One of them, A. T. a girl of 10 years, presented chronic nephritis and edema. The other two were boys, B. K. 8 years and J. G. 7 years, without edema or other evidence of renal disability. It was preferred to study the action of these several salts in the presence of edema in the same individual in order that findings might be dependably compared, which would not be the case were they obtained from several children requiring differing amounts of food and presenting various degrees of renal disease. A. T. proved a most suitable subject. Her chronic nephritis was of a year's duration and edema therefrom recurred gradually but regularly following removal by a diuretic agent. She remained cheerfully and healthily on the constant diet for several months and provided five periods of study. Single periods of study were obtained from the two children without edema.

\footnotetext{
${ }^{1}$ The diet was composed of cereal (Cream of Wheat), bread (salt poor), eggs, butter (salt free), milk, sugar and orange juice. The amounts given were measured by weight or volume. Of each article of food the same amount was given day by day. The cereal was cooked in a measured volume of $\mathrm{NaCl}$ solution which provided a usual degree of saltiness. The chloride intake was thus only moderately less than is contained in a usual diet.

The several children were given a caloric intake appropriate to their individual requirements.

The water intake was measured and was maintained at a usual level. This was for B. K. and J. G., 1000 cc. daily and for A. T. $1220 \mathrm{cc}$.
} 


\section{ACID PRODUCING SALTS}

As mentioned above $\mathrm{CaCl}_{2}$ taken orally has been shown (6) to be physiologically an acid substance by reason of a much greater absorption of $\mathrm{Cl}^{\prime}$ than of $\mathrm{Ca}$. from the gastro-intestinal tract. The similarity of certain physical properties of $\mathrm{Ca}^{*}$ and $\mathrm{Mg}^{*}$ suggests that from ingested magnesium salts the acid radical may be expected to enter the body fluids more extensively than $\mathrm{Mg}^{*}$.

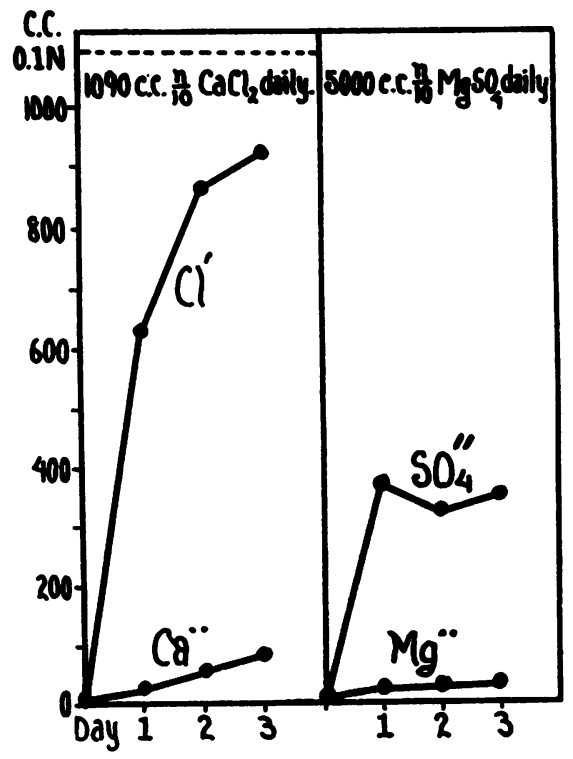

Fig. 1. Measurements of Acid and Basic Radicals in Urine from Ingested SALTS, $\mathrm{CaCl}_{2}$ AND $\mathrm{MgSO}_{4}$

Values given represent increase per 24 hours over fore period measurements

This explanation of an acid effect following ingestion of $\mathrm{CaCl}_{2}$ and of $\mathrm{MgSO}_{4}$ is illustrated by a few measurements, given in figure 1, showing the large excess of acid over basic radicals from these salts found in the urine. We may note incidentally that the excretion of $\mathrm{Cl}^{\prime}$ rapidly approaches the increased intake indicated by the broken line in the diagram whereas the amount of $\mathrm{SO}_{4}^{\prime \prime}$ found in the urine is only a small part of the quantity ingested. $\mathrm{CaCl}_{2}$ is thus indicated as producing a larger acid effect than $\mathrm{MgSO}_{4}$, apparently because of a less extensive absorption of $\mathrm{SO}_{4}^{\prime \prime}$ than of $\mathrm{Cl}^{\prime}$. 
In order to clearly indicate the acid character of ingested $\mathrm{NH}_{4} \mathrm{Cl}$, the behaviour of the chief factors in the management of the increased excretion of $\mathrm{Cl}^{\prime}$ following administration of $\mathrm{CaCl}_{2}$ and of $\mathrm{NH}_{4} \mathrm{Cl}$ is compared by means of a few measurements given in figure 2 . As

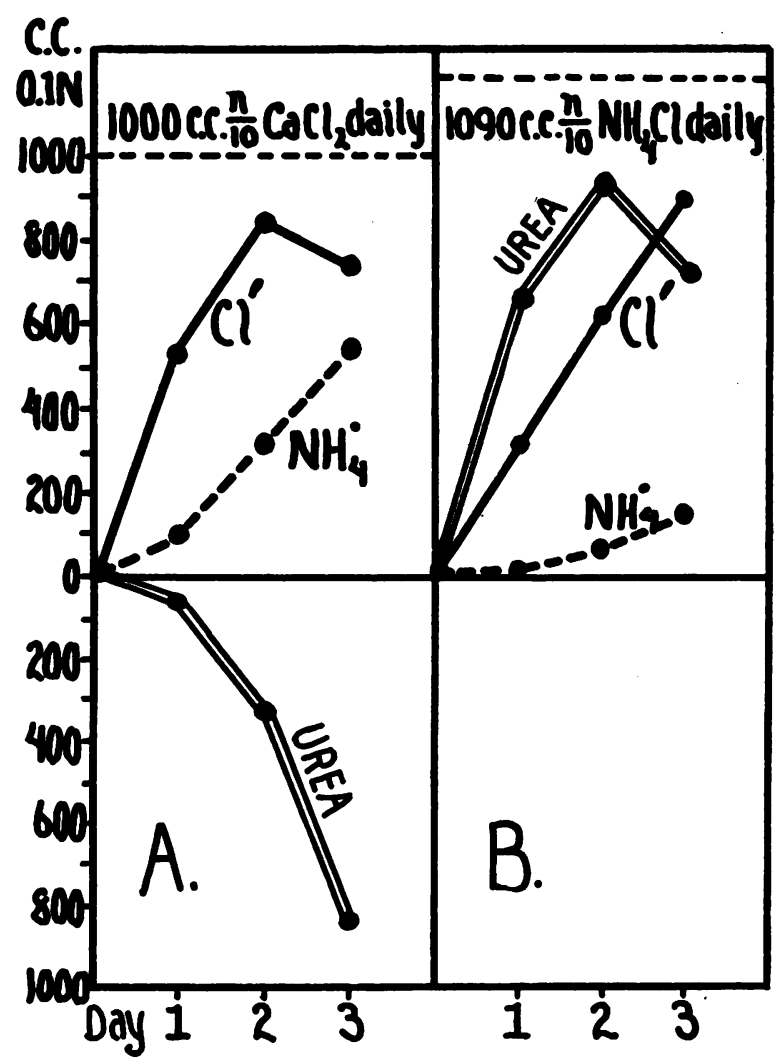

Fig. 2. Illustrating Ammonta-Urea Relationship in URINe Following INGESTION OF $\mathrm{CaCl}_{2}$ AND of $\mathrm{NH}_{4} \mathrm{Cl}$

Urea given as cc. $0.1 \mathrm{~N} \mathrm{NH}_{4}$, i.e., as twice its tenth molecular value. The values given represent increase per 24 hours over fore period measurements.

may be seen in diagram $\mathrm{A}, \mathrm{CaCl}_{2}$ produces a rise in $\mathrm{Cl}^{\prime}$ accompanied by a rise in $\mathrm{NH}_{4}^{-}$at the expense of urea as indicated by the roughly proportional decline in this value. The $\mathrm{NH}_{4}^{-}$increase is however considerably less than the extension of $\mathrm{Cl}^{\prime}$. In diagram $\mathrm{B}$, giving the 
measurements following ingestion of $\mathrm{NH}_{4} \mathrm{Cl}$, the rise in $\mathrm{NH}_{4}^{*}$ is even further short of the increase in $\mathrm{Cl}^{\prime}$, and the rise in urea indicates most of the ingested $\mathrm{NH}_{4}$ entering the urine as urea. The discrepancy between the increase in $\mathrm{Cl}^{\prime}$ and rise in $\mathrm{NH}_{4}^{-}$especially in the presence of edema is discussed below. These few data are presented here simply to make clear the point that ammonium salts to such extent as they are absorbed are to their full equivalence acids and in the management of their excretion the ingested $\mathrm{NH}_{4}$ is of no significance.

III. INCREASE IN PLASMA ACIDITY ACCOMPANYING THE DIURETIC ACTION OF ACID PRODUCING SALTS

Data illustrating the coincidence of plasma bicarbonate and $\mathrm{pH}$ lowering with a diuretic action produced by these salts, indicated by decrease in body weight ${ }^{2}$ and increase in urine volume, are given graphically in figures 3 and 4 . Figure 3 contains the measurements from B. K. (no edema). Calcium chloride gm. 5.5 per day was given over a period of 6 days. The data from A. T. (edema) are represented by the diagrams in figure 4 . She was given $\mathrm{CaCl}_{2}, \mathrm{NH}_{4} \mathrm{Cl}$, and $\left(\mathrm{NH}_{4}\right)_{2} \mathrm{SO}_{4}$ in turn, in each instance following a reaccumulation of edema and over a period of four days. $\mathrm{CaCl}_{2} \mathrm{gm} .6 .0$ was given in two $3.0 \mathrm{gm}$. doses for three days. After her morning dose on the 4th day she complained of gastric discomfort and for this reason the afternoon dose was omitted. The daily dose of $\mathrm{NH}_{4} \mathrm{Cl}$ was $5.8 \mathrm{gm}$. and of $\left(\mathrm{NH}_{4}\right)_{2} \mathrm{SO}_{4} 7.2 \mathrm{gm}$. and these amounts were given for three consecutive days. On the 4th day only the morning dose was given in order to conform with the quantity of salt given during the $\mathrm{CaCl}_{2}$ period of study. ${ }^{3}$ Incidentally it may be noted that following the morning dose on the 4th day she complained in both instances of nausea, although during the preceding three days the salt had been taken without the least gastric discomfort. In terms of tenth normal solutions the addition to the intake of acid radicals provided by these amounts of

${ }^{2}$ In the case of B. K. (No Edema), body weight measurements were, regrettably, not obtained.

${ }^{3}$ Solutions of salts were prepared providing the daily intake in the following amounts of water: $\mathrm{CaCl}_{2}, 100 \mathrm{cc}$; $\mathrm{NH}_{4} \mathrm{Cl}$ and $\mathrm{MgSO}_{4}, 200 \mathrm{cc}$. The larger amount in the case of the ammonia salts was used because of Haldane's statement that $\mathrm{NH}_{4} \mathrm{Cl}$, unless given in fairly dilute solution, tends to cause nausea. 
the several salts was in each instance $1090 \mathrm{cc} .0 .1 \mathrm{~N}$ per day for three days and $545 \mathrm{cc} .0 .1 \mathrm{~N}$ during the fourth day. In the case of B.K. the acid intake was slightly less, the $5.5 \mathrm{gm} . \mathrm{CaCl}_{2}$ providing $1000 \mathrm{cc} .0 .1 \mathrm{~N}$. The total excretion of inorganic acids in the urine from these children preceding ingestion of the acid producing salts was found to be about $1000 \mathrm{cc} .0 .1 \mathrm{~N}$ daily (see tables 2,3 and 4 , Section V), i.e. this quantity of inorganic acid radicals was derived daily from the constant diet. This value is mentioned here in order to indicate the very large addition to

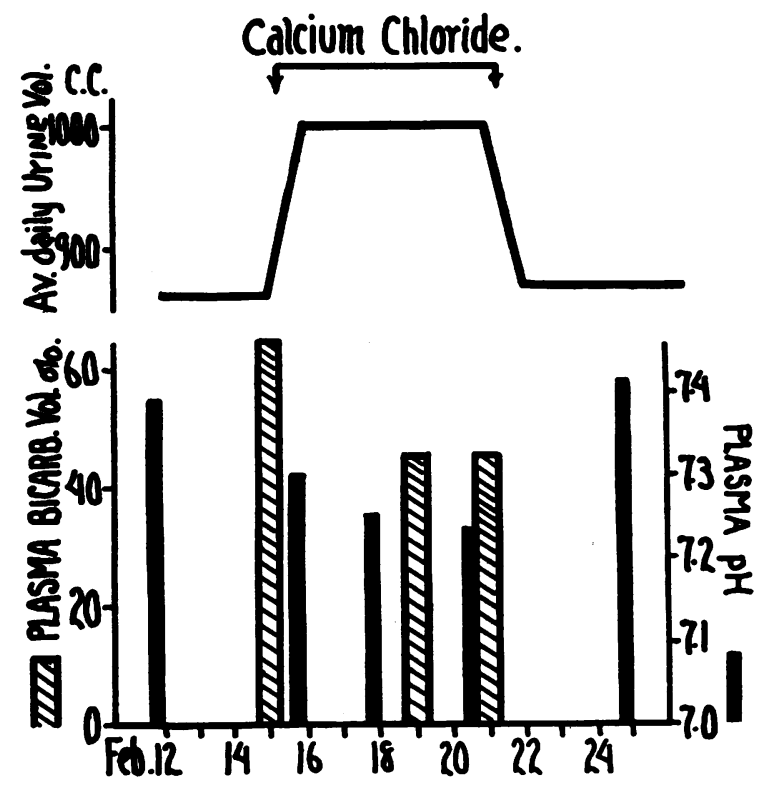

Fig. 3. Measurements from B. K. (No Edema) Illustrating Reduction of Plasma Bicarbonate and pH Accompanying Diuresis Produced by INGESTION OF $\mathrm{CaCl}_{2}$

the excretion of inorganic acids caused by administering these salts in amounts corresponding to the dosage of $\mathrm{CaCl}_{2}$ usually recommended as effective in obtaining diuresis. The fact that such amounts of the salts double the quantity of acid radicals claiming excretion in the urine under usual circumstances of acid-base metabolism and provide no appreciable increase of fixed base prepares us to find without surprise a considerable alteration of acid-base adjustments within the body. 


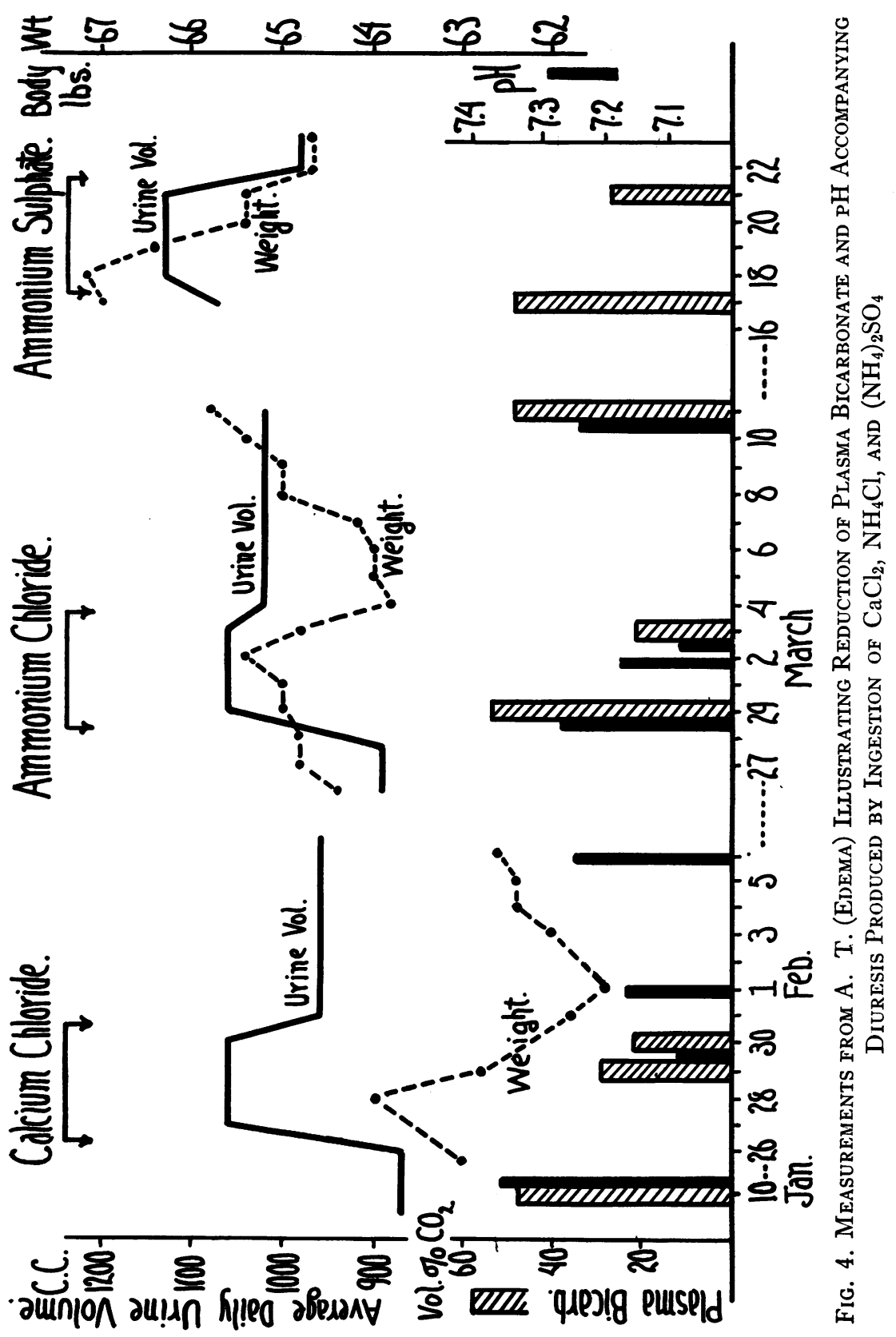


As may be seen in the diagrams, each of these salts exhibited definitely a diuretic action. The bicarbonate and $\mathrm{pH}$ measurements are more precisely given in the next section. They are used here simply to illustrate clearly the concurrence of diuresis with the marked acidosis which these salts produced. This relationship is so satisfactorily shown by the diagrams that further comment is unnecessary. It may here be mentioned that, so far as we are aware, an acidosis and diuretic action following ingestion of $\left(\mathrm{NH}_{4}\right)_{2} \mathrm{SO}_{4}$ has heretofore not been described.

\section{THE FACTORS IN THE CAUSATION OF AN INCREASED PLASMA ACIDITY BY ACID PRODUCING SALTS}

Gamble, Ross and Tisdall (6) found as mentioned above that following ingestion of $\mathrm{CaCl}_{2}$ the increase of $(\mathrm{BCl})$ in the plasma is closely of the same extent as the decrease of $\left(\mathrm{BHCO}_{3}\right)$. In agreement with this finding they also demonstrated that total fixed base in the plasma is not appreciably changed by administration of this salt. The reduction of bicarbonate is thus practically entirely referable to an extension of $\left(\mathrm{Cl}^{\prime}\right)$ which dispossesses $\left(\mathrm{HCO}_{3}^{\prime \prime}\right)$ of an equivalence of base. Haldane, Hill and Luck, in their paper appearing at the same time, also noted the close equivalence of the chloride increase and bicarbonate reduction in calcium chloride acidosis. Gamble and Ross (7) noted that $\mathrm{NH}_{4} \mathrm{Cl}$ given an infant with tetany produced closely reciprocal changes in $(\mathrm{BCl})$ and $\left(\mathrm{BHCO}_{3}\right)$ in the plasma and that, indicated by stationary values for $(\mathrm{Na})$, there was no appreciable loss of plasma base.

Data explaining the bicarbonate reduction seen in figures 3 and 4 are given in table 1 , and are also presented graphically by means of the diagrams in figure 5. The measurements (except those of $\mathrm{pH}$ ) are given as cc. $0.1 \mathrm{~N}$ per $100 \mathrm{cc}$. of plasma in order that they may be compared in terms of acid-base equivalence. ${ }^{4}$ It is believed that the

${ }^{4}$ The actual amount of univalent base bound in the plasma is $1.8 \times\left(\mathrm{HPO}_{4}^{\prime}\right)$; not twice the equivalence of the concentration of this radical as is suggested by the double valency symbol. This value is easily derived from the fact that, at $\mathrm{pH}$ $7.4,20 \%$ of $\left(\mathrm{HPO}_{4}^{\prime \prime}\right)$ is bound as $\mathrm{BH}_{2} \mathrm{PO}_{4}$ and 80 per cent as $\mathrm{B}_{2} \mathrm{HPO}_{4}$. The base equivalence of $\left(\mathrm{HPO}_{4}^{\prime}\right)$ is thus $0.2+(2 \times 0.8)=1.8$. This factor was used in obtaining the values given in the table and diagrams. It will be understood that 
diagrams exhibit more clearly and in better perspective than tabulated data the parts of the ionic structure in the plasma and the manner of their interdependence. The left hand column in each diagram represents the fixed base measurement. Laid off against this successively beginning at the top are the measurements of such acid values as were obtained. The unmeasured acid values are contained in the remainder of the acid column designated $\mathrm{R}$. These are three, $\mathrm{SO}_{4}^{\prime \prime}$, organic acids, and the base binding equivalence of the plasma proteins. ${ }^{5}$ Measure-

TABLE 1

Showing alterations of certain acid-base values in blood plasma caused by ingestion of acid producing salts

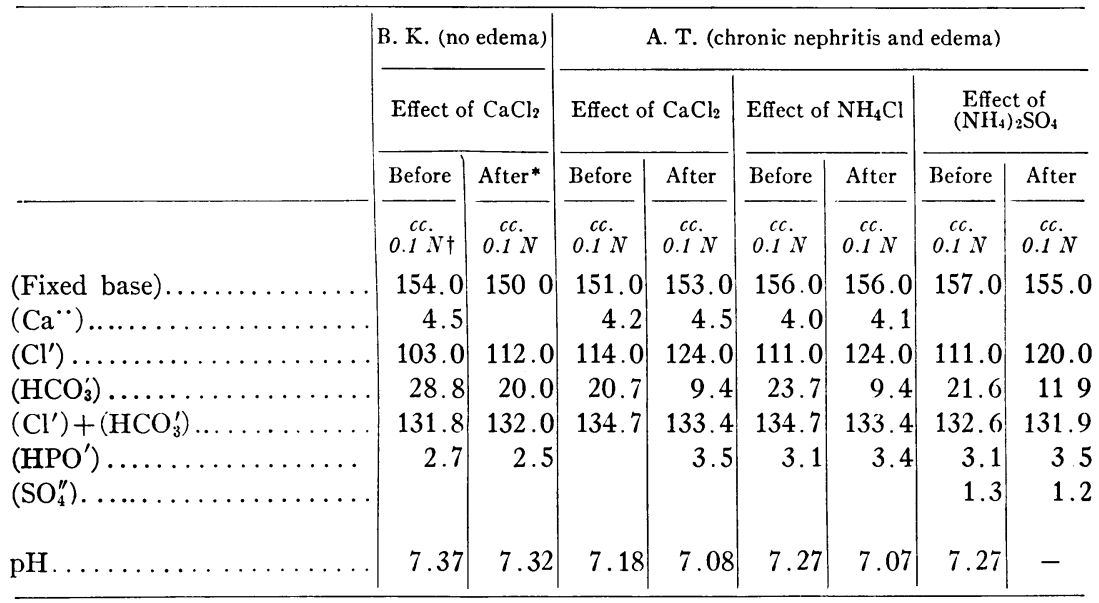

* Measurements in the columns marked "After" were obtained at the end of the 3rd day of salt administration.

$\dagger$ Per 100 cc. of plasma.

the measurements of $\left(\mathrm{HCO}_{3}^{\prime}\right)$ as determined by the Van Slyke method for plasma bicarbonate do not contain the approximately $1 / 20$ of the total $\left(\mathrm{HCO}_{3}^{\prime}\right)$ in the plasma which is present as $\mathrm{H} . \mathrm{HCO}_{3}$, so that as indicated these values for $\left(\mathrm{HCO}_{3}^{\prime}\right)$ cover a full equivalence of base. The base equivalence of $\left(\mathrm{Cl}^{\prime}\right)$ is of course 1.0 and that of $\left(\mathrm{SO}_{4}^{\prime \prime}\right)$ is 2.0 .

${ }^{5}$ As has been noted (4, page 367 ), among the three inorganic acid radicals only $\mathrm{HPO}_{4}^{\prime \prime}$ binds slightly less than its full valency equivalence of base in the plasma. $\left(\mathrm{Cl}^{\prime}\right)$ and $\left(\mathrm{SO}_{4}^{\prime \prime}\right)$ are fully covered by base both in the plasma and in urine. ( $\left.\mathrm{HPO}_{4}^{\prime \prime}\right)$ carries still less of base into acid urine than it binds in the plasma. By expressing the acid excretion in terms of base bound while being conveyed in the body fluids, an increase may be correctly compared with an accompanying increase in excretion of $\mathrm{NH}_{4}$ as a means of estimating fixed base withdrawal. 
ments of $\mathrm{SO}_{4}^{\prime \prime}$ are given in the last pair of diagrams. Adjustment of the acid side of this structure to the fixed base level is an automatic consequence of the elasticity of $\left(\mathrm{HCO}_{3}^{\prime}\right)$ and for this reason this value is appropriately placed at the top of the acid column. The acid side being adjustable, the importance of an accurate maintenance of fixed base from the point of view of preserving a correct total ionic content of the plasma is apparent.

In table 1 and in figure 5 it may be seen that in spite of the huge addition to the excess of acid over fixed base claiming excretion in the urine, the plasma fixed base remains closely stationary. It is not desired to intimate that the just measurable differences in this value are without significance. It is probable that small changes may considerably alter processes dependent on osmotic pressure adjustments. A discussion of these few data from this point of view is, however, not warranted here. As regards the large reduction of bicarbonate which evidently alters the $\left(\mathrm{BHCO}_{3}\right):\left(\mathrm{H}_{2} \mathrm{CO}_{3}\right)$ ratio to an extent producing a marked increase of plasma acidity, the measurements indicate that this change is not to appreciable extent caused by a depletion of plasma base. The relationship of $\left(\mathrm{BHCO}_{3}\right)$ reduction to the large rise in the level conveyance $\left(\mathrm{Cl}^{\prime}\right)$ is shown in the table by the nearly stationary values for the sum of $\left(\mathrm{HCO}_{3}^{\prime}\right)$ and $\left(\mathrm{Cl}^{\prime}\right)$, and may be seen at a glance in the diagrams. The acidosis produced by ingestion of $\mathrm{CaCl}_{2}$ or of $\mathrm{NH}_{4} \mathrm{Cl}$ is thus, as might be expected, understandable as a direct consequence of the greatly increased quantity of $\mathrm{Cl}^{\prime}$ demanding transport. It could scarcely have been anticipated however that a reduction of $\left(\mathrm{BHCO}_{3}\right)$ following ingestion of $\left(\mathrm{NH}_{4}\right)_{2} \mathrm{SO}_{4}$ would also be found to be caused by an equivalent extension of $\left(\mathrm{Cl}^{\prime}\right)$. The measurements of $\left(\mathrm{SO}_{4}^{\prime \prime}\right)$ were made with the expectation that increase in this value might explain the lowering of $\left(\mathrm{BHCO}_{3}\right)$. As may be seen however in table 1 and figure 5 the relatively very small concentration at which $\left(\mathrm{SO}_{4}^{\prime \prime}\right)$ is carried in the plasma was not measurably altered by administration of $\left(\mathrm{NH}_{4}\right)_{2} \mathrm{SO}_{4}$ in spite of the fact that, during this period, about four times as much $\mathrm{SO}_{4}^{\prime \prime}$ was carried into the urine per day as during the fore period (see table 4, Section 5). That the immediate cause of reduction of $\left(\mathrm{BHCO}_{3}\right)$ after giving $\left(\mathrm{NH}_{4}\right)_{2} \mathrm{SO}_{4}$ is an extension of $\left(\mathrm{Cl}^{\prime}\right)$ just as occurs following ingestion of $\mathrm{CaCl}_{2}$ or $\mathrm{NH}_{4} \mathrm{Cl}$ is clearly apparent in the diagrams in figure 5. This large increase in $\left(\mathrm{Cl}^{\prime}\right)$, related in 


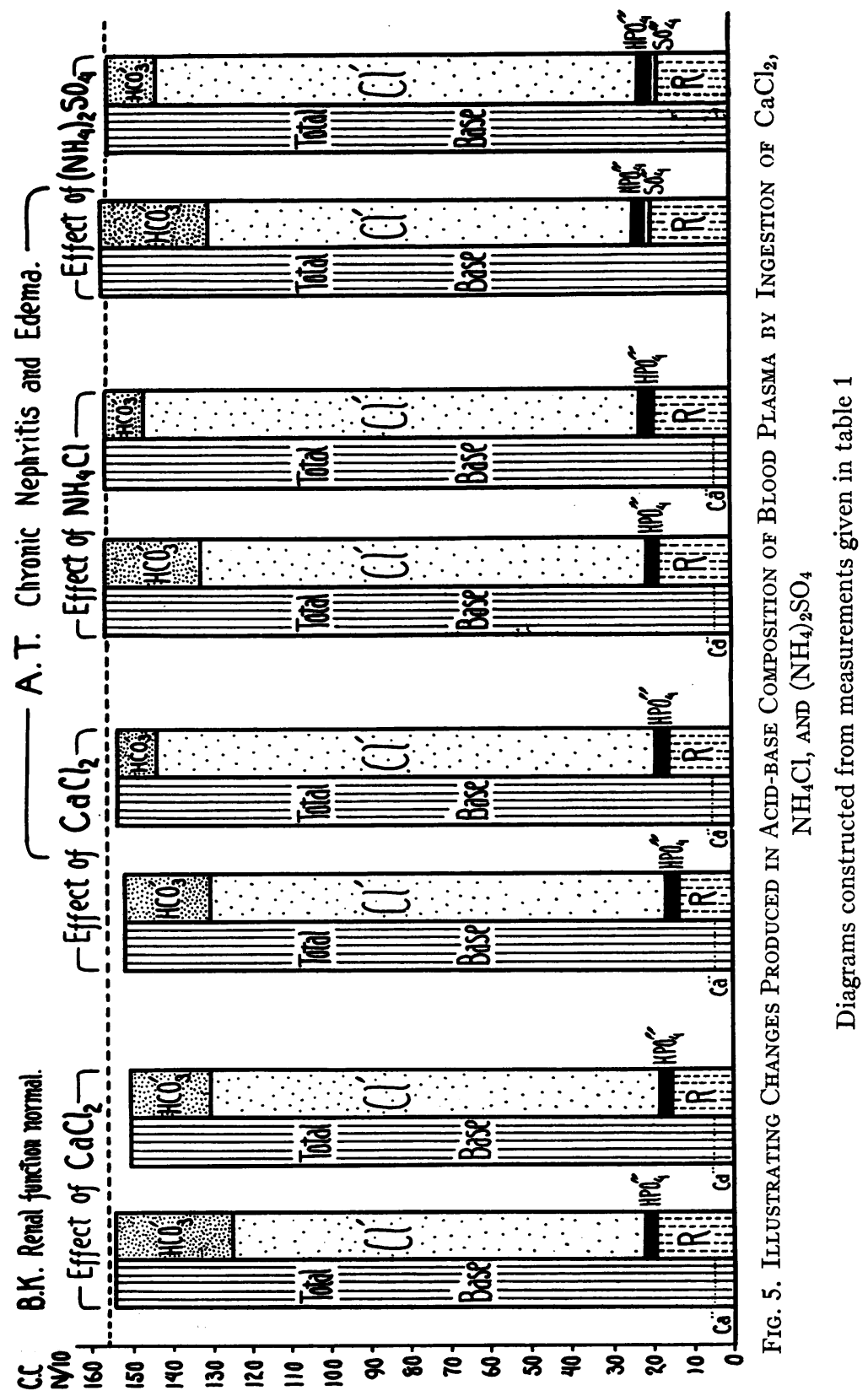


some way to an increased metabolism of $\mathrm{SO}_{4}^{\prime \prime}$ must be of considerable significance as regards the rôle of $\left(\mathrm{Cl}^{\prime}\right)$ in the mechanism managing acid-base adjustments in the body fluids. This significance, however, is not easily discernible and it is desired here simply to report this finding without surmise as to its import.

Measurements of $\left(\mathrm{HPO}_{4}^{\prime \prime}\right)$ were obtained to cover the possibility that phosphate retention might be a factor in $\left(\mathrm{BHCO}_{3}\right)$ reduction in the case of the nephritic child A. T. No appreciable increase of this plasma acid was found. As regards the extent to which phosphate retention may be a factor in producing acidosis, it should be appreciated that a relatively very large increase in $\left(\mathrm{HPO}_{4}^{\prime \prime}\right)$ would be necessary in order to cause any considerable reduction of $\left(\mathrm{BHCO}_{3}\right)$. If the usual magnitudes of these values as shown in figure 5 be compared, it will be apparent that $\left(\mathrm{HPO}_{4}^{\prime \prime}\right)$ must increase several fold to cause a moderate reduction of $\left(\mathrm{BHCO}_{3}\right)$. In contrast, a 20 per cent increase in $\left(\mathrm{Cl}^{\prime}\right)$ will lower $\left(\mathrm{BHCO}_{3}\right)$ by more than one-half of its usual value. Marriott and Howland (11) and, later, Denis and Minot (12) have published measurements of phosphate retention in nephritis, a few of which are of a magnitude sufficient to reduce a normal $\left(\mathrm{BHCO}_{3}\right)$ by one-third or even by one-half. Such values were, however, nearly always obtained in the terminal and uremic phase of the disease.

The calcium measurements given in table 1 demonstrate that this base factor in the plasma is not appreciably altered by ingestion of large amounts of a calcium containing salt. It remains somewhat below its usual value which may be taken as $5.0 \mathrm{cc} .0 .1 \mathrm{~N}$ per $100 \mathrm{cc}$. of plasma. This lowering of $\left(\mathrm{Ca} \cdot{ }^{*}\right)$ is a usual finding in nephritis with edema. The slight extent to which the fixed base of the plasma is composed of $\left(\mathrm{Ca}^{*}\right)$ is indicated in the diagrams (figure 5). That reduction of $\left(\mathrm{BHCO}_{3}\right)$ produced by these salts in the manner just described is accompanied by a marked increase in plasma acidity is shown by the direct measurements of plasma $\mathrm{pH}$ given in table 1 .

An important point appearing in these data is the fact that the changes in the plasma produced by these salts, viz., increase in $\left(\mathrm{Cl}^{\prime}\right)$ reducing $\left(\mathrm{BHCO}_{3}\right)$ and thus increasing acidity, were found to be already established to a considerable degree in the case of $\mathrm{A}$. T., the child with nephritis and edema, before the salts were given. The degree of chloride acidosis presented by $\mathrm{A}$. T. (edema) before ingestion 
of the salts may be appreciated by a glance at the diagrams in figure 5. For instance, before $\mathrm{CaCl}_{2}$ was given, $\left(\mathrm{Cl}^{\prime}\right)$ was found increased and $\left(\mathrm{HCO}_{3}^{\prime}\right)$ reduced to approximately the extent found in the plasma from B. K. (no edema) after ingestion of this salt, as may be seen by comparing these adjacent diagrams. Since an increased acidity of the plasma brought about by a rise in $\left(\mathrm{Cl}^{\prime}\right)$ is found to be accompanied by an increased rate of removal of water from the body, it is perhaps not unreasonable to regard the unusually high $\left(\mathrm{Cl}^{\prime}\right)$ observed in the plasma of A. T., not as a retention in the pathological sense, but as a beneficial adjustment in the presence of an obstacle imposed by disease. As possibly supporting this interpretation of the increased $\left(\mathrm{Cl}^{\prime}\right)$ it may be pointed out that the resultant rise in plasma acidity must be regarded as surprisingly large if our customary assumption that even very considerable reductions of $\left(\mathrm{BHCO}_{3}\right)$ are closely compensated for by respiratory adjustment is correct. As further comment in this direction, it may be suggested that the finding of an altered factor in the plasma should not constitute an unqualified indication to restore it by some direct means to its usual value. At any rate in this instance in the presence of an acidosis, not bicarbonate, but a salt increasing the degree of plasma acidity, produces an apparently desirable therapeutic result, viz., a removal of superfluous body water.

V. THE INCREASE IN FIXED BASE EXCRETION IN THE URINE AND BEHAVIOR OF THE FACTORS OF ACID EXCRETION FOLLOWING INGESTION OF ACID PRODUCING SALTS

The increase in the excess of acid over fixed base claiming excretion in the urine caused by ingestion of acid producing salts must obviously be accompanied by an equivalent extension of the factors which spare the use of fixed base in the process of acid excretion if withdrawal of fixed base from the body is to be prevented. The conveyance of an acid excess into the urine is, as has been shown by Henderson (13) and Henderson and Palmer (14), undertaken by the operation together of two adjustments; a regulated production of ammonia at the expense of urea and an absolute saving of base obtained by secretion of urine at a $\mathrm{pH}$ lower than that of blood plasma. Ammonia production is usually the larger and is also much the more extensible of these two factors. Under the circumstances present in these studies, increase in 
ammonia production is practically the only adjustment available during the periods of increase in acid excess, for the reason that the fore period urines are of a reaction near the physiological limit of acidity so that no appreciable increase in base saving is obtainable by the slight further lowering of urine $\mathrm{pH}$ which is possible. A glance at the few data represented in the diagrams in figure 2 will serve to clearly indicate the fact that extension of the ammonia factor falls far short of the increase in excretion of the acid radical of the ingested salt. It may be correctly inferred from these data that the discrepancy between the increase of $\mathrm{Cl}^{\prime}$ and that of $\mathrm{NH}_{4}$ indicates a withdrawal of fixed base from the body. We should not, however, regard $\mathrm{Cl}^{\prime}-\mathrm{NH}_{4}$ as accurately measuring the increase in fixed base excretion without first testing the possibility of minor alterations in the metabolism levels of the other acid radicals in the presence of the large increase in the intake of $\mathrm{Cl}^{\prime}$. In order to determine fairly completely all of the factors in the situation, the following measurements were obtained from 24-hour urine specimens collected before, during, and following the periods of salt administration: volume, $\mathrm{pH}$, inorganic sulphates and phosphates, chlorides, ammonia, fixed base, and as a means of estimating the accuracy of collection of the 24-hour urine specimen, creatinine. Because of the presence of albumin in the specimens from A. T. (edema), measurements of the titratable acidity of the urine and of the organic acid excretion were not undertaken. As has just been mentioned, the base-saving factor which is measured by the titratable acidity of the urine is not appreciably operative in covering the increase in acid excess produced by the salts. These data are contained in tables 2, 3, and 4; the measurements of base being given as cc. $0.1 \mathrm{~N}$ and those of the inorganic acid radicals as cc. $0.1 \mathrm{~N}$ of base equivalence at the reaction of blood plasma. Except for those obtained during a period of $\mathrm{MgSO}_{4}$ administration to $\mathrm{A}$. T. and given in the upper section of table 4 , the measurements in these tables were obtained during the periods of study which supplied the data given in the preceding section. Attention may perhaps be first directed to certain small changes in the excretion levels of the acids other than the one contained in the ingested salt. As may be seen in table 3-A, the large increase in $\mathrm{Cl}^{\prime}$ in urine during ingestion of $\mathrm{CaCl}_{2}$ by $\mathrm{A}$. $\mathrm{T}$. is accompanied by definite decrease in $\mathrm{HPO}_{4}^{\prime \prime}$ excretion and also a just discernible reduction of 
$\mathrm{SO}_{4}^{\prime \prime}$. The increase in total acid excretion due to $\mathrm{Cl}^{\prime}$ is thus in this instance to a slight extent offset by a decrease in $\mathrm{HPO}_{4}^{\prime \prime}$ and $\mathrm{SO}_{4}^{\prime \prime}$. These changes can be reasonable explained as due to a reduction of $\mathrm{HPO}_{4}^{\prime \prime}$ and $\mathrm{SO}_{4}^{\prime \prime}$ absorption caused by an increased formation of insoluble calcium phosphates and sulphates in the intestine. They are not, however, distinctly apparent in the urines from B. K. when the same salt was given (see table 2). As would be expected on the basis of the surmise just offered, administration of $\mathrm{NH}_{4} \mathrm{Cl}$ did not lower the excretion levels of $\mathrm{HPO}_{4}^{\prime \prime}$ and $\mathrm{SO}_{4}^{\prime \prime}$ (see table 3-B). In table 4 may be

TABLE 2

B. K. (no edema). Calcium chloride period of study. Measurements from 24-hour urine specimens

\begin{tabular}{|c|c|c|c|c|c|c|c|c|c|c|c|c|}
\hline \multirow{2}{*}{ Day } & \multirow{2}{*}{$\begin{array}{l}\mathrm{CaCl}_{2} \\
\text { Ingested }\end{array}$} & \multirow{2}{*}{$\begin{array}{l}\text { Urine } \\
\text { volume }\end{array}$} & \multirow{2}{*}{$\begin{array}{l}\text { Creat- } \\
\text { inine }\end{array}$} & \multirow{2}{*}{$\mathrm{pH}$} & \multirow{2}{*}{$\mathrm{SO}_{4}{ }^{\prime \prime}$} & \multirow{2}{*}{$\mathrm{HPO}_{4}$} & \multirow{2}{*}{$\mathrm{Cl}^{\prime}$} & \multirow{2}{*}{$\mathrm{NH}_{\mathrm{i}}$} & \multirow{2}{*}{$\begin{array}{c}\text { Fixed } \\
\text { base }\end{array}$} & \multicolumn{3}{|c|}{$\begin{array}{l}\text { Increase over fore } \\
\text { period. }\end{array}$} \\
\hline & & & & & & & & & & $\mathrm{Cl}^{\prime}$ & $\mathrm{NH}_{i}$ & $\begin{array}{c}\text { Fixed } \\
\text { base }\end{array}$ \\
\hline & $0.1 N$ & $c c$. & $m g$. & & $0.1 \mathrm{~N}$ & $0.1 \mathrm{~N}$ & $0.1 \mathrm{~N}$ & $0.1 \mathrm{~N}$ & $0.1 \mathrm{~N}$ & $0.1 \mathrm{~N}$ & $0.1 \mathrm{~N}$ & $0.1 \mathrm{~N}$ \\
\hline $1-4$ & 0 & 860 & 355 & 5.9 & 236 & 357 & 354 & 228 & 548 & & & \\
\hline 1 & 1000 & 1040 & 360 & 5.0 & 229 & 317. & 891 & 326 & 931 & 534 & 98 & 383 \\
\hline 2 & 1000 & 1060 & 398 & 4.7 & 246 & 348 & 1191 & 549 & 1072 & 837 & 321 & 524 \\
\hline 3 & 1000 & 930 & 348 & 5.0 & 231 & 316 & 1086 & 776 & 686 & 732 & 548 & 138 \\
\hline 4 & 1000 & 1100 & 366 & 5.1 & 265 & 338 & 1257 & 840 & 745 & 903 & 612 & 197 \\
\hline 5 & 1000 & 860 & 370 & 5.3 & 233 & 238 & 1186 & 986 & 566 & 832 & 758 & 18 \\
\hline 6 & 1000 & 1010 & 418 & 5.3 & 313 & 335 & 1257 & 1123 & 651 & 903 & 895 & 103 \\
\hline 1 & 0 & 940 & 325 & 6.2 & 252 & 299 & 700 & 928 & 250 & 346 & 700 & -298 \\
\hline 2 & 0 & 670 & 333 & 6.0 & 280 & 306 & 393 & 680 & 171 & 39 & 452 & -377 \\
\hline 3 & 0 & 910 & 349 & 6.0 & & 319 & 371 & 461 & 306 & 17 & 233 & -242 \\
\hline 4 & 0 & 800 & 333 & 5.9 & & 343 & 450 & 325 & 584 & 96 & 97 & 36 \\
\hline
\end{tabular}

seen during the first several days of the $\mathrm{MgSO}_{4}$ and $\left(\mathrm{NH}_{4}\right)_{2} \mathrm{SO}_{4}$ periods a fairly large increase in $\mathrm{Cl}^{\prime}$. An explanation of this event will be undertaken below. As indicated in figure 1, the fixed base excretion contains only to a slight extent $\mathrm{Ca}^{*}$ or $\mathrm{Mg}{ }^{*}$ from the ingested salt. All of these changes just noted are, however, relatively small. The increase in total acid excretion may therefore be approximately determined by measuring the increase in the urine of the acid radical of the ingested salt and, by subtracting from this value the ammonia increase, the withdrawal of fixed base from the body may be fairly 
closely estimated. We were, however, at pains to directly measure the fixed base excretion by the method of Fiske. The chief purpose of

TABLE 3

Data from A. T. (edema). Calcium chloride and ammonium chloride periods of study. Measurements from consecutive 24-hour urine specimens

\begin{tabular}{l|l|l|l|l|l|l|l|l|l|l|l|}
\hline Day & $\begin{array}{c}\text { Salt } \\
\text { given }\end{array}$ & $\begin{array}{c}\text { Urine } \\
\text { volume }\end{array}$ & $\begin{array}{c}\text { Creat- } \\
\text { inine }\end{array}$ & $\mathrm{pH}$ & $\mathrm{SO}_{4}^{*}$ & $\mathrm{HPO}_{4}^{*}$ & $\mathrm{Cl}^{\prime}$ & $\mathrm{NH}$ & $\begin{array}{c}\text { Fixed } \\
\text { base }\end{array}$ & \multicolumn{2}{|c|}{$\begin{array}{c}\text { Increase over fore } \\
\text { period. }\end{array}$} \\
\hline $\mathrm{Cl}^{\prime}$ & $\mathrm{NH}_{i} \begin{array}{c}\text { Fixed } \\
\text { base }\end{array}$ \\
\hline
\end{tabular}

A. $\mathrm{CaCl}_{2}$ period

\begin{tabular}{|c|c|c|c|c|c|c|c|c|c|c|c|c|}
\hline & $0.1 \mathrm{~N}$ & $c c$. & mg. & & $0.1 \mathrm{~N}$ & $\begin{array}{l}c c . \\
0.1 \mathrm{~N}\end{array}$ & $0.1 \mathrm{~N}$ & $0.1 \mathrm{~N}$ & $0.1 \mathrm{~N}$ & $\begin{array}{c}c c . \\
0.1 N\end{array}$ & $0.1 N$ & $0.1 \mathrm{~N}$ \\
\hline $1-3$ & 0 & 870 & 525 & 5.0 & 196 & 331 & 443 & 339 & 530 & & & \\
\hline 1 & 1090 & 1000 & 520 & 5.0 & 164 & 164 & 1071 & 336 & 974 & 628 & -3 & 444 \\
\hline 2 & 1090 & 1130 & 544 & 5.0 & 205 & 205 & 1307 & 461 & 1088 & 864 & 122 & 58 \\
\hline 3 & 1090 & 990 & 520 & 5.0 & 196 & 258 & 1357 & 518 & 1394 & 914 & 179 & 864 \\
\hline 4 & 545 & 1140 & 528 & 5.0 & 156 & 248 & 1018 & 488 & 864 & 575 & 149 & 334 \\
\hline 1 & 0 & 970 & 521 & 5.0 & 221 & 315 & 686 & 586 & 576 & 243 & 247 & 46 \\
\hline 2 & 0 & 870 & 578 & 5.1 & 261 & 342 & 650 & 600 & 572 & 207 & 261 & 42 \\
\hline 3 & 0 & 1040 & 506 & 5.2 & 235 & 311 & 471 & 721 & 523 & 28 & 382 & -7 \\
\hline 4 & 0 & 910 & 470 & 5.2 & 220 & 306 & 529 & 529 & 461 & 86 & 190 & -69 \\
\hline 5 & 0 & 950 & 470 & 5.2 & 194 & 324 & 479 & 475 & 471 & 36 & 136 & -59 \\
\hline 6 & 0 & 815 & 525 & 5.1 & 194 & 313 & 457 & 407 & 495 & 14 & 68 & -35 \\
\hline
\end{tabular}

B. $\mathrm{NH}_{4} \mathrm{Cl}$ period

\begin{tabular}{r|r|r|r|r|l|l|r|r|r|r|r|r}
\hline $1-3$ & 0 & 870 & 450 & 4.6 & 215 & 340 & 390 & 261 & 562 & &. & - \\
1 & 1090 & 1000 & 540 & 4.6 & 217 & 331 & 700 & 266 & 862 & 310 & 5 & 300 \\
2 & 1090 & 980 & 540 & 4.6 & 218 & 325 & 1007 & 342 & 1086 & 617 & 81 & 524 \\
3 & 1090 & 1200 & 522 & 4.9 & 217 & 359 & 1286 & 435 & 1388 & 896 & 174 & 826 \\
4 & 545 & 890 & 580 & 4.9 & 197 & 334 & 807 & 438 & 872 & 417 & 177 & 310 \\
& & & & & & & & & & & & \\
1 & 0 & 975 & 555 & 4.9 & 209 & 331 & 700 & 486 & 632 & 310 & 225 & 70 \\
2 & 0 & 1050 & 522 & 4.9 & 202 & 305 & 634 & 520 & 608 & 244 & 259 & 46 \\
3 & 0 & 960 & 555 & 4.9 & 201 & 322 & 586 & 452 & 570 & 196 & 191 & 8 \\
4 & 0 & 895 & 540 & 4.9 & 187 & 325 & 521 & 425 & 526 & 131 & 164 & -36 \\
5 & 0 & 1130 & 522 & 4.9 & & 369 & 463 & 414 & 468 & 73 & 153 & -94 \\
6 & 0 & 1000 & 540 & 4.8 & 182 & 331 & 393 & 361 & 544 & 3 & 100 & -18 \\
\hline
\end{tabular}

these data being to illustrate the manner and extent of fixed base removal from the body during administration of acid producing salts, 
the three essential measurements are those of the increase in urine of the acid radical of the ingested salt, ammonia, and fixed base, over fore period values. The values found for these three factors are given in heavy faced type in the last three columns of the tables. In order to make their relationship easily apparent, they are, except for the

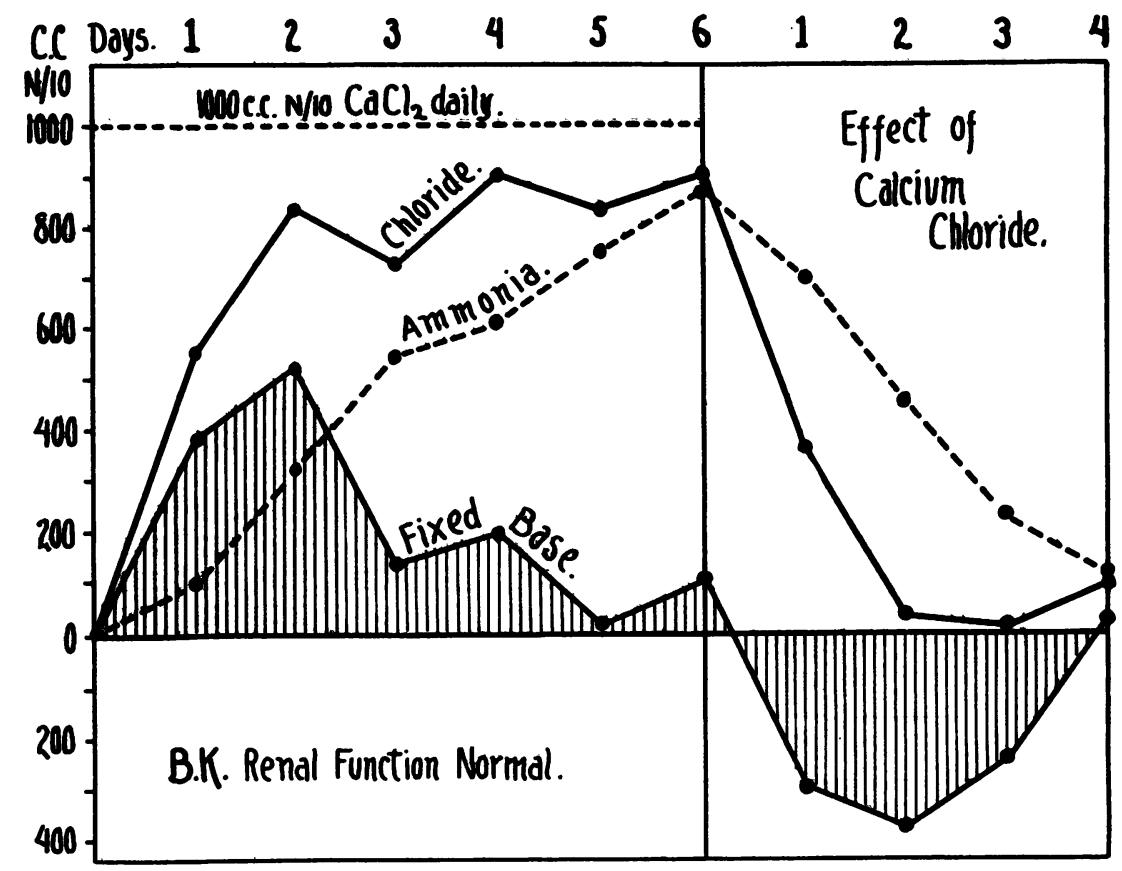

Fig. 6. Data from B. K. (No Edema) Representing Factors Determining an Increased Excretion of Fixed Base in Urine During a 6-Day Period of $\mathrm{CaCl}_{2}$ Administration

Measurements are those of increase over fore period values given in heavy faced type in table 2 .

measurements obtained during the $\mathrm{MgSO}_{4}$ period, also presented graphically by means of the diagrams in figures 6 and 7 . The base line in these diagrams is the fore period level, increase being plotted above and decrease below this line. Diagrams presenting the results of two additional periods of study are given in figure 8. These were obtained from A. T. (edema) and J. G. (no edema) before, during, and 


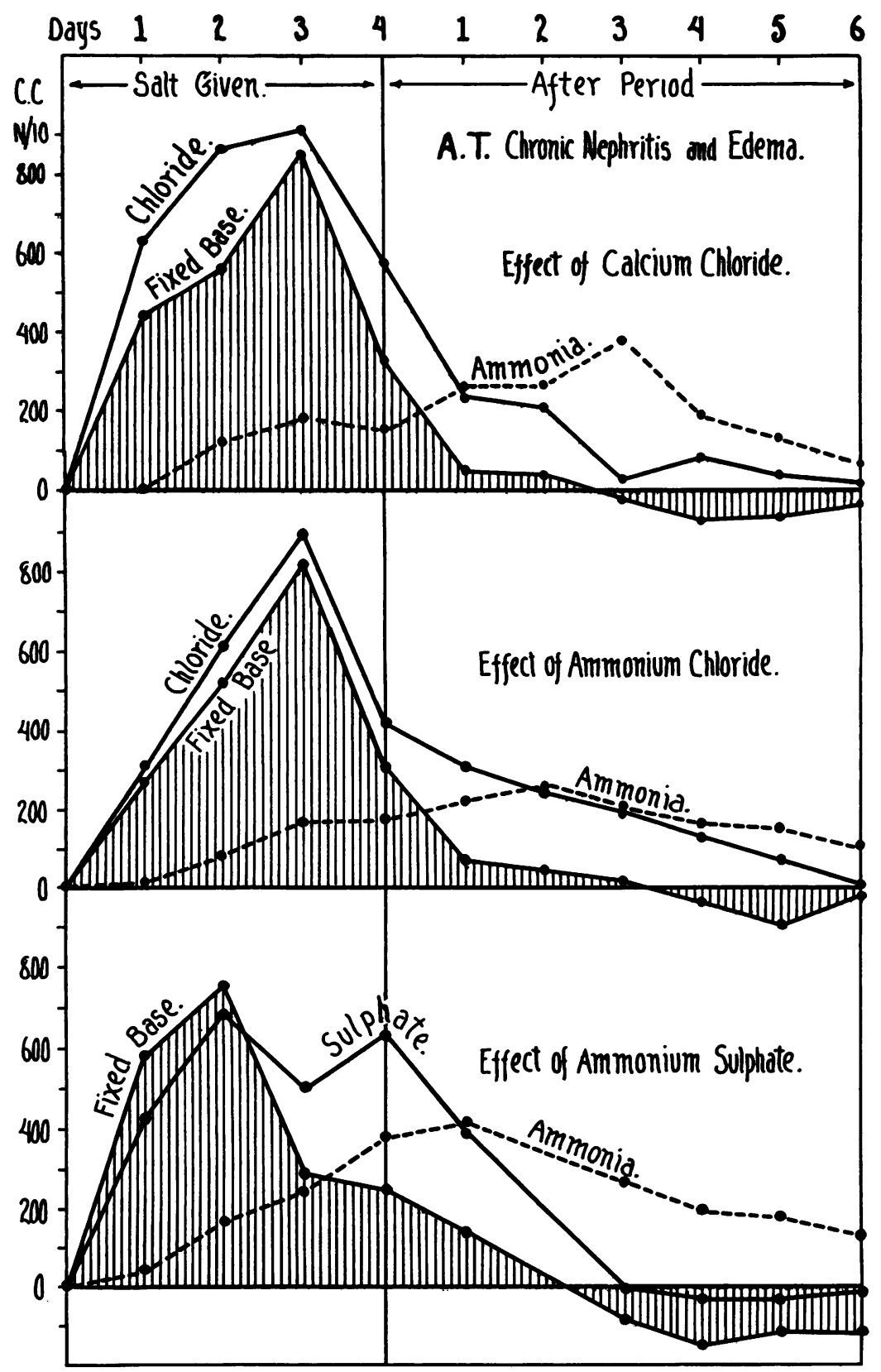

Fig. 7. Data from A. T. (Edema) Representing Factors Determining an InCreased Excretion of Fixed Base in Urine During 4-Day Periods of INGESTION of $\mathrm{CaCl}_{2}, \mathrm{NH}_{4} \mathrm{Cl}$, AND of $\left(\mathrm{NH}_{4}\right)_{2} \mathrm{SO}_{4}$

Measurements are those of increase over fore period values given in heavy faced type in tables 3 and $4-B$. 
following 8-day periods of administration of $\mathrm{NH}_{4} \mathrm{Cl}$, gm. 3.0, per day, i.e., approximately one-half the amount of salt given A. T. during the period already described.

The diagrams will, it is believed, make unnecessary more than brief comment on the urine findings. The rough agreement of fixed base withdrawal with the extent to which $\mathrm{NH}_{4}^{*}$ fails to cover the acid increase is easily apparent. Attention may be called to the nearly identical character of the diagrams in figure 7 representing changes in the three factors produced by ingestion of equivalent amounts of $\mathrm{CaCl}_{2}$ and of $\mathrm{NH}_{4} \mathrm{Cl}$. The fact that there is essentially no difference in the manner and extent of base withdrawal caused by these salts would seem to quite clearly indicate that, in the case of $\mathrm{CaCl}_{2}, \mathrm{Ca}$. plays no rôle in this action. The lower diagram in the figure illustrating the changes produced by an equivalent amount of $\left(\mathrm{NH}_{4}\right)_{2} \mathrm{SO}_{4}$ fairly closely resembles those of the acid chloride periods. The fact that the fixed base points at first lie above those measuring the $\mathrm{SO}_{4}^{\prime \prime}$ increase is explained by an accompanying increase in $\mathrm{Cl}^{\prime}$ during the first two days of the period (see table 4). Absorption of $\mathrm{SO}_{4}^{\prime \prime}$ when given as $\left(\mathrm{NH}_{4}\right)_{2} \mathrm{SO}_{4}$ is thus seen to be practically as extensive as that of $\mathrm{Cl}^{\prime}$ from $\mathrm{CaCl}_{2}$ or $\mathrm{NH}_{4} \mathrm{Cl}$. In contrast may be noted the much smaller amounts of $\mathrm{SO}_{4}^{\prime \prime}$ found in the urine when $\mathrm{MgSO}_{4}$ in much larger dosage was given (see table 4). This difference is in part, but probably not entirely, due to the fact that the large amount of $\mathrm{MgSO}_{4}$ given produced copious catharsis. It may be mentioned here that during none of the other periods of study did the salts in the amounts used cause catharsis. The data in table 4-A are given simply to demonstrate that $\mathrm{MgSO}_{4}$ is to slight extent an acid producing salt and, in addition to its action as an intestinal hydragogue, causes also to a measureable extent a removal of fixed base by way of the kidney. As regards a probable practical usefulness of $\left(\mathrm{NH}_{4}\right)_{2} \mathrm{SO}_{4}$ as a diuretic agent, it may be further mentioned that in solution it is very much less disagreeable tasting than $\mathrm{CaCl}_{2}$ or $\mathrm{NH}_{4} \mathrm{Cl}$.

Another chief point which these data demonstrate is that the acid producing salts when given the child with nephritis and edema caused a more rapid and longer sustained removal of fixed base than occurred when such a salt was taken by B. K. or by J. G., the children without edema or renal disease. This difference may be seen at a glance by 
comparing the diagrams (figures 6 and 7) representing the measurements obtained during the $\mathrm{CaCl}_{2}$ periods of B. K. (no edema) and A. T.

TABLE 4

Data from A. T. (edema). Magnesium sulphate and ammonium sulphate periods of study. Measurements from consecutive 24-hour urine specimens

\begin{tabular}{|c|c|c|c|c|c|c|c|c|c|c|c|c|}
\hline \multirow{2}{*}{ Day } & \multirow{2}{*}{$\begin{array}{c}\text { Salt } \\
\text { given }\end{array}$} & \multirow{2}{*}{$\begin{array}{l}\text { Urine } \\
\text { volume }\end{array}$} & \multirow{2}{*}{$\begin{array}{l}\text { Creat- } \\
\text { inine }\end{array}$} & \multirow{2}{*}{$\mathrm{pH}$} & \multirow{2}{*}{$\mathrm{SO}_{4}{ }^{\prime \prime}$} & \multirow{2}{*}{$\mathrm{HPO}_{4}$} & \multirow{2}{*}{$\mathrm{Cl}^{\circ}$} & \multirow{2}{*}{$\mathrm{NH}_{4}$} & \multirow{2}{*}{$\begin{array}{l}\text { Fixed } \\
\text { base }\end{array}$} & \multicolumn{3}{|c|}{$\begin{array}{l}\text { Increase over fore } \\
\text { period. }\end{array}$} \\
\hline & & & & & & & & & & $\mathrm{Cl}^{\prime}$ & NHi & $\begin{array}{c}\text { Fixed } \\
\text { base }\end{array}$ \\
\hline
\end{tabular}

A. $\mathrm{MgSO}_{4}$ period

\begin{tabular}{|c|c|c|c|c|c|c|c|c|c|c|c|c|}
\hline & 0.1 i & $c c$. & mg. & & $0.1 \mathrm{~N}$ & $0.1 \mathrm{~N}$ & $\begin{array}{c}c c . \\
0.1\end{array}$ & $\begin{array}{r}c c . \\
0.1 N\end{array}$ & $\begin{array}{l}c c . \\
0.1 \mathrm{~N}\end{array}$ & $0.1 \mathrm{~N}$ & $\begin{array}{l}c c . \\
0.1 N\end{array}$ & $\begin{array}{r}c c . \\
0.1 \mathrm{~N}\end{array}$ \\
\hline $1-3$ & 0 & 840 & 490 & 4.9 & 212 & 302 & 428 & 196 & 674 & & & \\
\hline 1 & 5000 & 940 & 500 & 4.8 & 583 & 290 & 379 & 230 & 948 & 371 & 36 & 274 \\
\hline 2 & 5000 & 1125 & 495 & 4.8 & 532 & 331 & 839 & 275 & 1194 & 320 & 79 & 520 \\
\hline 3 & 5000 & 720 & 480 & 4.8 & 561 & 363 & 529 & 317 & 748 & 349 & 121 & 74 \\
\hline 4 & 5000 & 710 & 475 & 4.9 & 448 & 328 & 543 & 375 & 616 & 236 & 179 & -58 \\
\hline 5 & 2500 & 715 & 475 & 4.9 & 364 & 305 & 321 & 375 & 562 & 152 & 179 & -112 \\
\hline 6 & 2500 & 815 & 505 & 4.9 & 583 & 325 & 400 & 404 & 808 & 371 & 208 & 134 \\
\hline 7 & 2500 & 720 & 475 & 4.9 & 647 & 305 & 357 & 367 & 851 & 435 & 171 & 177 \\
\hline 8 & 2500 & 760 & 505 & 4.9 & 773 & 305 & 357 & 379 & 889 & 561 & 183 & 215 \\
\hline $1-3$ & 0 & 726 & 500 & 5.0 & 396 & 342 & 386 & 436 & 600 & 183 & 240 & -74 \\
\hline
\end{tabular}

B. $\left(\mathrm{NH}_{4}\right)_{2} \mathrm{SO}_{4}$ period

\begin{tabular}{l|r|r|r|r|r|r|r|r|r|r|r|r}
\hline $1-3$ & 0 & 1070 & 520 & 4.4 & 204 & 320 & 370 & 187 & 521 & & & \\
& & & & & & & & & & & & \\
1 & 1090 & 1200 & 564 & 4.4 & 636 & 331 & 489 & 232 & 1104 & 432 & 45 & 583 \\
2 & 1090 & 1280 & 572 & 4.4 & 892 & 358 & 520 & 358 & 1277 & 688 & 171 & 756 \\
3 & 1090 & 1025 & 523 & 4.8 & 705 & 319 & 306 & 433 & 814 & 501 & 246 & 293 \\
4 & 545 & 1030 & 550 & 4.8 & 843 & 364 & 306 & 565 & 772 & 639 & 378 & 251 \\
& - & & & & & & & & & & & \\
1 & 0 & 1115 & 545 & 5.0 & 602 & 338 & 403 & 591 & 662 & 398 & 404 & 141 \\
$2^{*}$ & 0 & & & & & & & & & & & \\
3 & 0 & 900 & 575 & 5.2 & 199 & 319 & 457 & 458 & 438 & -5 & 271 & -83 \\
4 & 0 & 960 & 515 & 5.2 & 171 & 290 & 400 & 382 & 372 & -33 & 195 & -149 \\
5 & 0 & 1000 & 495 & 5.2 & 175 & 296 & 386 & 370 & 406 & -29 & 183 & -115 \\
6 & 0 & 920 & 525 & 5.0 & 186 & 288 & 386 & 323 & 400 & -18 & 136 & -121 \\
\hline
\end{tabular}

* Collection of 24-hour specimen was incomplete.

(edema), and the immediate cause of the larger withdrawal of fixed base from A. T. is at once discernible in the sluggish rise of the line 
measuring $\mathrm{NH}_{4}$ increase in contrast with its rapid ascent in the case of B. K., the rate of acid increase in the urine being approximately the - same for both subjects. The differences in the behaviour of the three factors in the presence and in the absence of nephritis and edema during

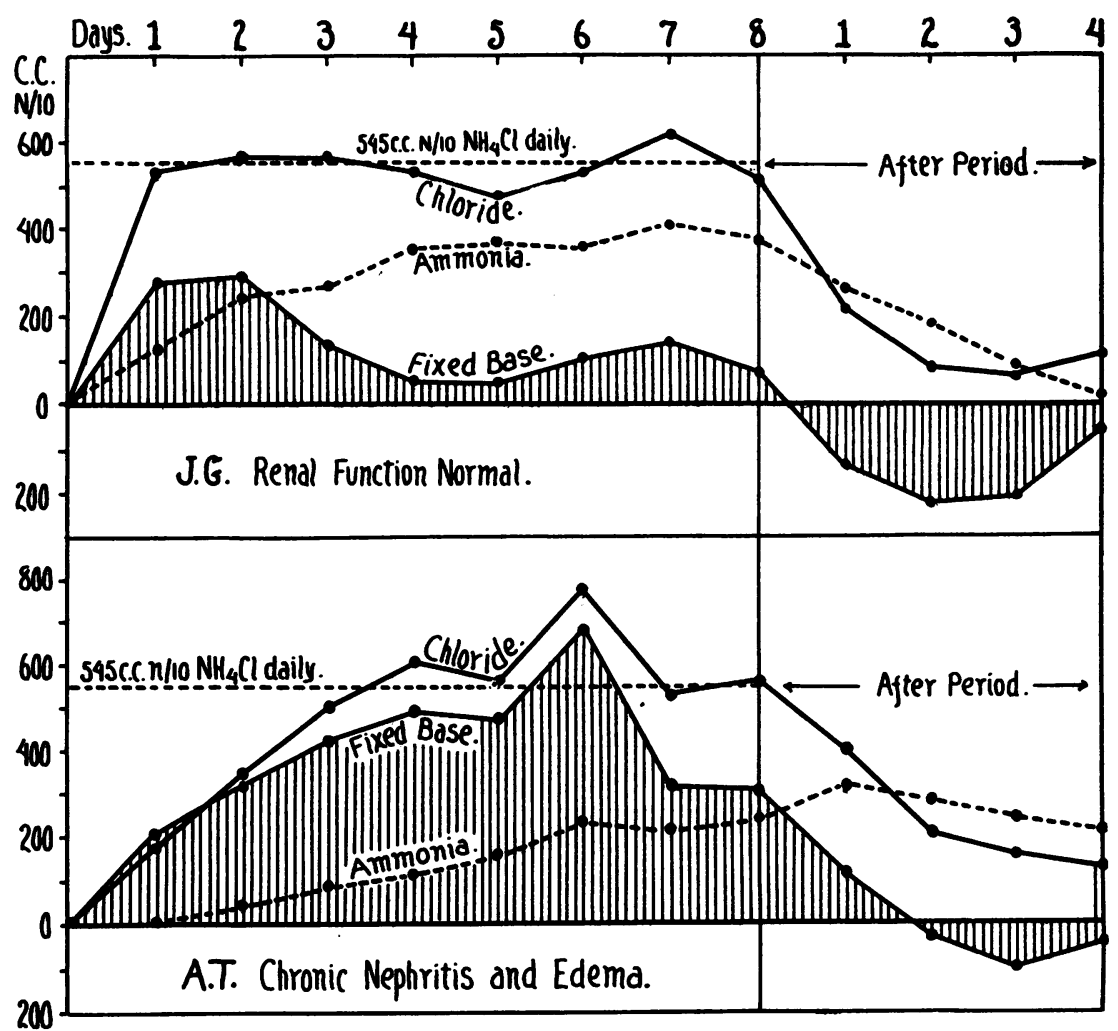

Fig. 8. Data from J. G. (No Edema) and A. T. (Edema) Representing Factors Determining an Increased Excretion of Fixed Base in Urine During 8-day Periods of $\mathrm{NH}_{4} \mathrm{Cl}$ Administration

Measurements are of increase per 24 hours over fore period values

longer periods of ingestion of smaller amounts of salt, in this case $\mathrm{NH}_{4} \mathrm{Cl}$, by A. T. (edema) and by J. G. (no edema) are shown by the diagrams in figure 8 . The slower rise in ammonia production and in consequence the much larger loss of fixed base in the case of A. T. (edema) are here seen again. In these diagrams may be noted a 
difference in the rate of $\mathrm{Cl}^{\prime}$ removal which does not appear in the data from the $\mathrm{CaCl}_{2}$ periods of A. T. and B. K. Here, in contrast with the prompt appearance of the added $\mathrm{Cl}^{\prime}$ intake in the urine from $\mathrm{J}$. G. (no edema), the increase in $\mathrm{Cl}^{\prime}$ excretion mounts gradually in the case of A. T. (edema), the initial lag, however, being made up for by an ultimate rise above the level of added intake, indicated by the broken line across the chart. To compare in total values the loss of base from these two children; the sum of the daily measurements of increase in fixed base excretion during the 8 days of $\mathrm{NH}_{4} \mathrm{Cl}$ administration is $1129 \mathrm{cc} .0 .1 \mathrm{~N}$ for J. G. (no edema) and $3332 \mathrm{cc} .0 .1 \mathrm{~N}$ for A. T. (edema). During the 4-day after periods J. G. regained $613 \mathrm{cc}$. $0.1 \mathrm{~N}$ and A. T. only $160 \mathrm{cc} .0 .1 \mathrm{~N}$.

Having indicated the manner and extent of the increased excretion of fixed base in the urine during the periods of administration of acid producing salts it is obviously necessary to undertake to explain the closely stationary concentration of fixed base in blood plasma shown by the data given in the preceding section. The terms of the situation practically demonstrate its explanation. Assuming a maintenance of absolutely stationary concentrations of fixed base in the body fluids in the presence of a removal of fixed base into the urine, it is only possible to infer an accurately proportional reduction of the volume of the body fluids from which the fixed base loss derives. The measurements of plasma base given in Section III, while regarded as demonstrating only an approximately stationary concentration, are nevertheless so near the usual value as to indicate with certainty a close relationship between the loss of body water and the increased excretion of fixed base. Data illustrating the closely proportional withdrawal of body water accompanying the excretion of fixed base in urine during periods of fasting have been published by Gamble, Tisdall and Ross (15). It is therefore permissible to regard the increase in excretion of fixed base in urine shown above as roughly measuring the diuretic action of the acid producing salts. The increase of $\mathrm{Cl}^{\prime}$ in the urine accompanying the diuretic action of $\mathrm{MgSO}_{4}$ or of $\left(\mathrm{NH}_{4}\right)_{2} \mathrm{SO}_{4}$ can be satisfactorily explained in terms of the conception here being used. At least in blood plasma, $\mathrm{Cl}^{\prime}$ is the largest acid factor, covering about three-fifths of the total plasma base (see diagrams in figure 5). A loss of body water, especially if chiefly from 
the extra-cellular compartment, should therefore produce a considerable increase in the amount of $\mathrm{Cl}^{\prime}$ entering the urine. A withdrawal of $\mathrm{Cl}^{\prime}$ also occurs during the acid chloride periods. For instance it may be computed from the data used in constructing the diagrams in figure 8 that the increase of $\mathrm{Cl}^{\prime}$ in the urine for the 12-day periodswas actually more than the total of increased intake during the 8 days that $\mathrm{NH}_{4} \mathrm{Cl}$ was given. The values thus obtained are: increased intake (both subjects) $4760 \mathrm{cc} .0 .1 \mathrm{~N}$, increased excretion J. G. (no edema) 4827 cc. $0.1 \mathrm{~N}$ and A. T. (edema) 4974 cc. $0.1 \mathrm{~N}$ The surplus of $\mathrm{Cl}^{\prime}$ excretion over intake is thus larger in the case of A. T. (edema) corresponding appropriately to a larger removal of body water. Incidentally these data incidate an unimpaired ability of the kidney in the case of the nephritic child to eliminate $\mathrm{Cl}^{\prime}$ and support the surmise that the increase of $\left(\mathrm{Cl}^{\prime}\right)$ found in the plasma before administration of the salts (Section IV) should be regarded as an adjustment and not as a fault of renal function. These data also indicate the probability that the tendency to edema which ingestion of $\mathrm{NaCl}$ sometimes produces in nephritis is referable to $\mathrm{Na}$ and not to $\mathrm{Cl}^{\prime}$ and suggest that nephritic diets might safely and also beneficially, but unfortunately not palatably, contain the acid chlorides.

\section{COMPOSITION OF FIXED BASE EXCRETION IN URINE FOLLOWING INGESTION OF CALCIUM CHLORIDE}

The fixed base concentrations of the body fluids are composed chiefly of $\left(\mathrm{Na}^{\circ}\right)$ and $\left(\mathrm{K}^{\cdot}\right)$, the former constituting nearly all of the base in extra-cellular water and the latter at least two-thirds of the base in intra-cellular water. ${ }^{6}$ Regarding an increase in fixed base excretion as consisting of the base content of a portion of body water which has been removed, analysis of its composition, especially as regards $\mathrm{Na}^{\cdot}$ and $\mathrm{K}^{*}$, should serve to indicate the source of the withdrawn water. The amounts of $\mathrm{K}^{\cdot}, \mathrm{Ca}^{*}$ and $\mathrm{Mg}^{*}$ in the urine specimens collected during the calcium chloride periods of study from both B. K. (no edema) and A. T. (edema) were directly determined and a value for

${ }^{6}$ This statement is based on a comparison of the concentrations of the four bases in the water of blood plasma and of muscle tissue contained in a paper by Gamble, Ross and Tisdall (15) discussing fixed base metabolism. 
$\mathrm{Na} \cdot$ was obtained by subtracting the three other bases from the total fixed base measurement. These data are given in figure 9. Interpreting the measurements of $\mathrm{Na}^{\circ}$ and $\mathrm{K}^{*}$ according to the premise just suggested, the diagrams indicate a removal of water from both the

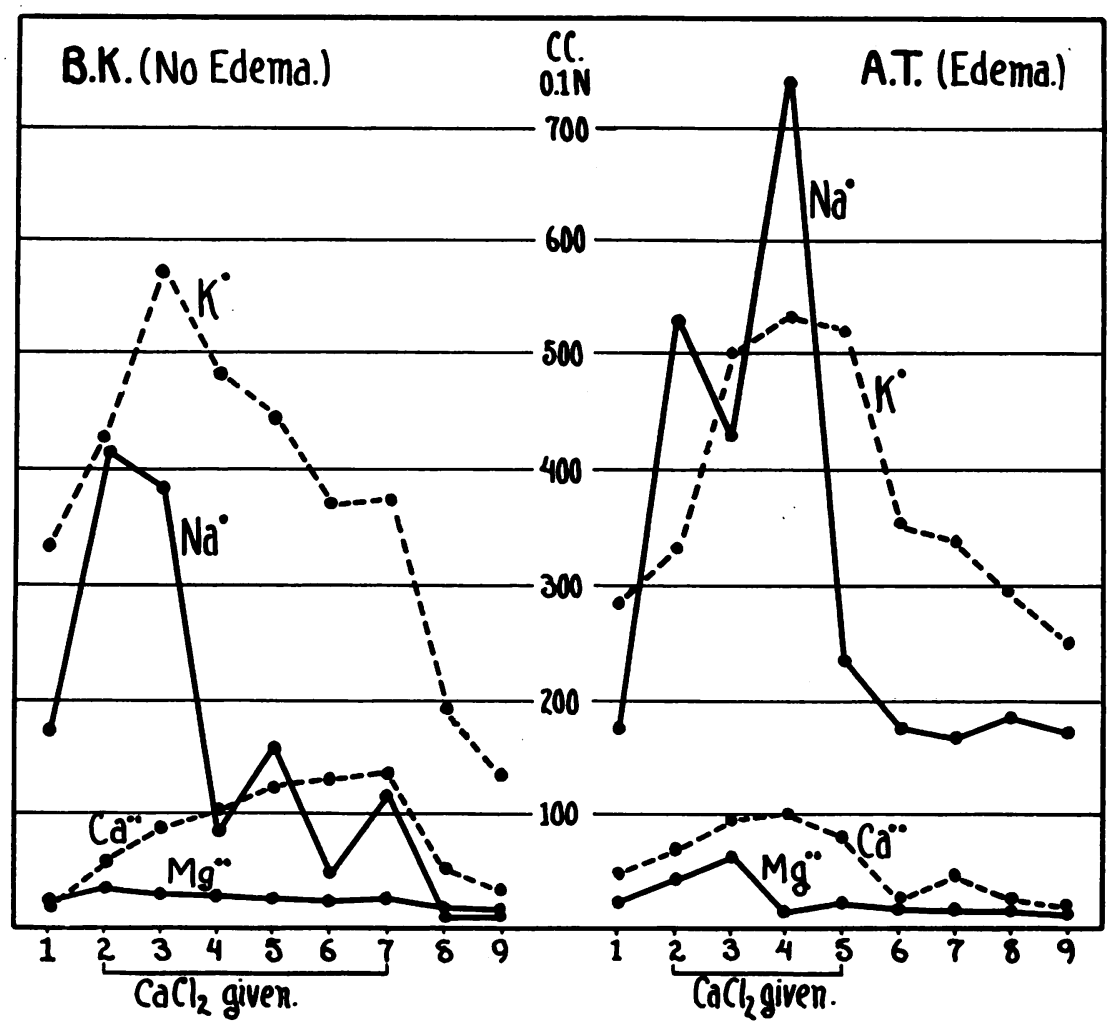

Fig. 9. Data from B. K. (No Edema) and A. T. (Edema) Showing Composition of Fixed. Base Excretion in Urine During 4-day Periods of $\mathrm{CaCl}_{2}$ Administration

Measurements from 24-hour urine specimens

intra- and extra-cellular compartments, from the former more rapidly at first and from the latter over a longer period. A glance at the diagrams also provides the information that in the case of $\mathrm{B}$. $\mathrm{K}$. (no edema) about the same amounts of extra- and of intra-cellular water have been withdrawn whereas the much larger water loss from 
A. T. (edema) is, as would be expected, largely composed of extracellular water. The data in table 5 will serve to illustrate further these differences as regards amount and source of the withdrawn water depending on the presence or absence of edema fluid in the body. The values given are for total increase of excretion of each of the four bases for the first four days and for the entire eight days of the study periods computed from the fore period values. Here may be noted the much larger excretion of $\mathrm{Na}^{\circ}$ than of $\mathrm{K}^{\cdot}$ during the period of $\mathrm{CaCl}_{2}$ administration in the case of $\mathrm{A}$. T. (edema) and also the lack of recovery of $\mathrm{Na}$ during the four-day after period. In contrast, B. K. loses rather more of $\mathrm{K}^{*}$ than of $\mathrm{Na}^{\circ}$ during the first four days and entirely replaces $\mathrm{Na}$ during the following four days although $\mathrm{CaCl}_{2}$ ingestion

TABLE 5

Composition of increase of fixed base excretion in urine produced by $\mathrm{CaCl}_{2}$

\begin{tabular}{|c|c|c|c|c|c|c|}
\hline Period & & $\begin{array}{c}\text { Total } \\
\text { fixed base }\end{array}$ & $\mathrm{Na}$ & $\mathrm{K}$ & $\mathrm{Ca}$ & $\mathrm{Mg}$ \\
\hline days & & cc. $0.1 \mathrm{~N}$ & cc. $0.1 \mathrm{~V}$ & $c c .0 .1 \mathrm{~N}$ & cc. $0.1 \mathrm{~N}$ & cc. $0.1 \mathrm{~V}$ \\
\hline \multirow{2}{*}{4} & 13. K. (no edema) & 1242 & 455 & 569 & 284 & 37 \\
\hline & A. T. (edema & 2200 & 1238 & 751 & 157 & 54 \\
\hline \multirow{2}{*}{8} & B. K. (no edema) & 688 & $-178^{*}$ & 296 & 553 & 29 \\
\hline & A. T. (edema) & 2212 & 1245 & 859 & 81 & 27 \\
\hline
\end{tabular}

* The minus sign here indicates that according to the rough method of obtaining this value the earlier loss of $\mathrm{Na}^{*}$ was to this extent more than replaced.

was continued through the first two of these days. A point of interest appearing in this table is the large total $(553 \mathrm{cc} .0 .1 \mathrm{~N})$ for increase in $\mathrm{Ca}{ }^{*}$ excretion for the eight-day period of B. K. (no edema). This value constitutes nearly all of the base deficit $(688 \mathrm{cc} .0 .1 \mathrm{~N})$ remaining at the end of the period. In the case of A. T. (edema) the much larger base deficit $(2212$ cc. $0.1 \mathrm{~N})$ contains a relatively very small amount (81 cc. $0.1 \mathrm{~N}$ ) of $\mathrm{Ca}^{*}$. That $\mathrm{Ca}^{*}$ may be withdrawn from $\mathrm{Ca}{ }^{*}$ deposits for use in the process of acid excretion in defense of the fixed base concentrations of the body fluids has been shown by Goto in the case of animals fed with mineral acids. Gamble, Ross and Tisdall found evidence that $\mathrm{Ca}$ " is used in this way during the acidosis produced by fasting. Here $\mathrm{Ca}^{\prime}$ is abundantly available from the ingested salt and it is interesting to find that in the case of a correct total fixed base 
content in the body (B. K.) Ca ${ }^{*}$ seems to be used defensively whereas in the presence of superfluous fixed base (and water) the excretion of $\mathrm{Ca}{ }^{*}$ in the urine is apparently so managed as not to appreciably obstruct a removal of $\mathrm{Na}^{\circ}$ and $\mathrm{K}^{\circ}$.

\section{DISCUSSION}

In undertaking to explain the diuretic action of acid producing salts in terms of the findings given above, we unfortunately at once encounter a familiar dilemma. Is the removal of body water a consequence of a forced withdrawal of fixed base or, vice versa, is a reduction of the volume of body water the initial event? We may fairly reasonably imagine that the huge addition to the excess of acid over fixed base presenting for excretion in the urine when these salts are given overtaxes the factors defending fixed base in the body fluids and produces a loss of fixed base which is accompanied by the water which contained it within the body. If this be the case, and regarding the kidney as the locus of the regulated production of ammonia, as has been well argued by Nash and Benedict (16), the much larger removal of fixed base obtained in the presence of nephritis may be plausibly explained by assuming that advantage is here taken of a disabled ammonia factor. Such an explanation excellently suits the relationship of the three factors as displayed in the diagrams in Section V, but does not well agree with the fact that non-nephritic edema may sometimes be effectively treated by ingestion of acid producing salts.

The alternative view of the sequence of events following ingestion of the acid producing salts consists in surmising a reduction in the volume of body water caused by the demonstrated increase in acidity and possibly other physico-chemical changes. The volume of body water being set at lower level in consequence of alteration of internal factors controlling it, the mechanism regulating the excretion of fixed base correctly permits the cast out body water to carry with it its content of base. A causative relationship of an increased acidity in the body fluids to secretion of a portion of body water may not at present be assumed with the certainty that applies in referring the increased fixed base excretion to the deficit in ammonia production. We have, however, the knowledge that an increased acidity in the body fluids 
lowers the base binding capacity of protein; a change which must according to the terms of the Donnan equilibrium theory considerably alter osmotic pressure adjustments between the several compartments of body water. According to J. B. S. Haldane (9), the changes produced by an increased acidity should favor a movement of water in the direction of the kidney. The view that the diuretic action of these acid producing salts is in some way a consequence of the increased acidity which they produce in the body fluids is obviously the preferable one since it includes in the mechanism of this action the striking alterations of structural factors found in the blood plasma and also permits a quite satisfactory explanation of the increased excretion of fixed base in the urine.

\section{SUMMARY}

Following ingestion of $\mathrm{CaCl}_{2}, \mathrm{NH}_{4} \mathrm{Cl}, \mathrm{MgSO}_{4}$ or of $\left(\mathrm{NH}_{4}\right)_{2} \mathrm{SO}_{4}$ in considerable amounts, the quantity of inorganic acid radicals which must be conveyed through the body fluids is greatly increased without an appreciable accompanying increase in the amount of fixed base presenting for transport. These salts are for this reason described as acid producing.

Administration of these acid producing salts causes an increased acidity of the body fluids demonstrable in the blood plasma and an increased excretion of fixed base in the urine. The immediate cause of the increased acidity of the body fluids is an extension of $\left(\mathrm{Cl}^{\prime}\right)$ with the result that, fixed base remaining fairly stationary $\left(\mathrm{BHCO}_{3}\right)$ is equivalently reduced, a change which is only slightly compensated for by respiratory adjustment of $\left(\mathrm{H}_{2} \mathrm{CO}_{3}\right)$. This increase of $\left(\mathrm{Cl}^{\prime}\right)$ is found following administration of the sulphates as well as after ingestion of the chlorides. In the presence of edema and nephritis an acidosis due to extension of $\left(\mathrm{Cl}^{\prime}\right)$ was found to be already established before the acid producing salts were given. Probably in consequence, the degree of increased plasma acidity found after administration of the salts was much greater than in the case of subjects without edema and having an initially usual plasma $\left(\mathrm{Cl}^{\prime}\right)$. The increased excretion of fixed base in the urine represents a deficit in the increase of ammonia production as compared with the increase in acid excretion caused by the ingested salt and was found to be much larger and longer sustained in the presence of edema. 
The changes which the acid producing salts cause in the blood plasma are accompanied by a removal of body water which, as indicated by the nearly stationary values for fixed base found in the plasma, is closely proportional to the increase of fixed base excretion in the urine. Regarding the composition of the increase in fixed base excretion as indicating the source of the withdrawn body water, an analysis of this increase shows a withdrawal of both extra- and of intra-cellular water, of the former at first more rapidly and of the latter over a longer period. In the presence of edema much the greater part of the water removed is from the extra-cellular compartment.

The diuretic action of these salts may probably be correctly referred to the increase in acidity of the body fluids which they all, as regards immediate cause, produce in an identical manner. The change in reaction is of such degree that it must according to the terms of the Donnan equilibrium theory considerably alter osmotic pressure values in the body fluids, and these alterations may reasonably be suspected as the factors in the ensuing removal of a portion of body water. In the presence of a reduction of the volume of body water, the increased excretion of fixed base in the urine is easily understandable as a correct adjustment of the mechanism controlling fixed base excretion in defense of a stationary concentration within the body.

\section{CHEMICAL METHODS USED}

\section{Blood plasma values}

These, except for $\mathrm{pH}$, were actually obtained in samples of blood serum for the reason that the total fixed base measurement obviously could not be obtained in oxalated or citrated samples. "Plasma" being for purposes of discussion the more suitable term, is used throughout and the probably very slight error contained in the assumption that plasma values may be measured in serum samples is neglected. The blood samples were collected in a Luer glass syringe and then delivered through small bore glass tubing and under oil into $15 \mathrm{cc}$. centrifuge tubes which were filled to the top and stoppered with a one-hole rubber stopper, permitting expulsion of superfluous oil, and the hole then closed with a glass plug. References to descriptions of the methods used are as follows: Total Fixed Base, Fiske (17); Bicarbanate, Van Slyke (18); Chlorides, Fiske (to be published); Phosphates (inorganic), Briggs (19); Sulphates (inorganic), Denis (20); Calcium, Kramer and Tisdall (21), with the alteration that, instead of using the permanganate titration, the ppt. was ignited in a platinum dish then dissolved in $0.015 \mathrm{HCl}$ and titrated back with $0.01 \mathrm{~N} \mathrm{NaOH}$ (suggested by Fiske). $\mathrm{pH}$ was determined in 
separately obtained samples by a modification of Cullen's colorimetric method devised by Hawkins (22).

\section{Urine values}

Total Fixed Base, Fiske (17);Chlorides, Volhard titration; Phosphates (inorganic), Briggs (19); Sulphates (inorganic), Fiske (23); Ammonia, Folin and MacCallum (24); Potassium, Tisdall and Kramer (25); Calcium, some of the measurements were obtained by the method of McCrudden (26) and others by the micro-method of Tisdall and Kramer (25); Magnesium, McCrudden (26) and also Briggs (27); $p H$, Palmer and Henderson (28). Toluol was the preservative used during collection of the 24-hour specimens.

\section{BIBLIOGRAPHY}

1. Blum, L. Comp. rend. Soc. de Biol., 1921, lxxxv, 950 and 1159. Bull. et Mém. Soc. méd. d. hôp. de. Paris. 1921, xlv, 1504.

2. Brelet, M. Gaz. d. hôp., 1922, xcv, 905.

3. Atchley, D. W., Loeb, R. F., and Benedict, E. M. Jour. Amer. Med. Ass., 1923, lxxx, 1643.

4. Rockwood, R. and Barrier, C. W. Arch. Int. Med., 1924, xxxiii, 643.

5. Fischer, M. Oedema and Nephritis, Ed. 2, New York, 1915.

6. Gamble, J. L., Ross, S. G., and Tisdall, F. F. Amer. Jour. Dis. Child., 1923, $\mathrm{xxv}, 455$.

7. Gamble, J. L., and Ross, S. G. Amer. Jour. Dis. Child., 1923, xxv, 470.

8. Haldane, J. B. S. Jour. Physiol., 1921, lv, 265.

9. Haldane, J. B. S., Hill, R., and Luck, J. M. Jour. Physiol, 1923, lvii, 301.

10. Keith, N., Barrier, C. W., and Whelan, M. Jour. Amer. Med. Ass., 1924, Ixxxiii, 666.

11. Marriott, W. McK., and Howland, J. Arch. Int. Med., 1916, xviii, 708.

12. Denis, W., and Minot, A. S. Arch. Int. Med., 1920, xxv, 99.

13. Henderson, L. J. Amer. Jour. Physiol., 1908, xxi, 427.

14. Henderson, L. J., and Palmer, W. W. Jour. Biol. Chem., 1914, xvii, 305.

15. Gamble, J. L., Ross, S. G., and Tisdall, F. F. Jour. Biol. Chem., 1923, lvii, 643.

16. Nash, T. P., Jr., and Benedict, S. R. Jour. Biol. Chem., 1921, xlviii, 463.

17. Fiske, C. H. Jour. Biol. Chem., 1922, li, 55.

18. Van Slyke, D. D. Jour. Biol. Chem., 1917, xxx, 347.

19. Briggs, A. P. Jour. Biol. Chem., 1922, liii, 13.

20. Denis, W. Jour. Biol. Chem., 1921, xlix, 311.

21. Kramer, B. J., and Tisdall, F. F. Jour. Biol. Chem., 1921, xlvii, 475.

22. Hawkins, J. A. Jour. Biol. Chem., 1923, lvii, 493.

23. Fiske, C. H. Jour. Biol. Chem., 1921, xlvii, 59.

24. Folin, O., and MacCallum, A. B. Jour. Biol. Chem., 1912, xi, 523.

25. Tisdall, F. F., and Kramer, B. Jour. Biol. Chem., 1921, xlviii, 1.

26. McCrudden, F.H. Jour. Biol. Chem., 1911, x, 187.

27. Briggs, A. P. Jour. Biol. Chem., 1922, lii, 349.

28. Palmer, W. W., and Henderson, L. J. Arch. Int. Med., 1913, xii, 153. 